\title{
Human Frontiers in rough water
}

An imaginative international research project, the Japanese-inspired Human Frontier Science Program, must not be allowed to founder because its managers wish it were something else and more conventional.

DR Edward Rall, of the US National Institutes of Health, and chairman of the council of management of the Human Frontier Science Program (HFSP) based at Strasbourg, must by now regret having complained to his fellow council members at the publication of Professor Akiyoshi Wada's article in Nature $(357,356 ; 1992)$. The essence of the complaint (see page 527) is that Wada, who had been a member of the project's scientific council since its inception, had not sought the approval of the management and science councils of the project, and of the project's secretary general, Sir James Gowans, before publishing his article. Rall's circular letter seems to overlook the circumstance that Wadas term of office came to an end earlier this year. Unwisely, Rall has taken sides in a long-simmering disagreement between Gowans and the Japanese, who founded the HFSP and who are still the chief sources of its support.

Gowans, an immunologist by trade, is an excellent scientist with eight years experience as head of Britain's Medical Research Council. Much of his spell at Strasbourg, which comes an end next March, has helped to strengthen the HFSP, notably by securing the membership of Sweden and Australia. But even Gowans' friends would not rate diplomacy high among his skills. Wada's article implied that Gowans has been out of sympathy with the Japanese wish that the HFSP should tackle problems different and more adventurous in kind from those now commonplace in the world's molecular and cell biology laboratories. The wish may be difficult to realize, but why does Rall believe it is improper that it should be mentioned publicly? The more serious difficulty, not mentioned publicly, is that Gowans has been at loggerheads with Japanese administrative staff at Strasbourg and has given Japanese members of the project's councils the impression that he is scornful of their opinions. Whether Gowans has been right or wrong, Rall must surely appreciate that the disaffection of an important project's major sponsors is too big a risk to run, especially by pleading that open discussion should be suppressed.

On the substance of the dispute, the Japanese are surely correct. From the outset, they sought true interdisciplinarity in the way the Human Frontier Science Program would function. What, for example, do systems engineers have to say about the interlocking metabolic reactions by which cells sustain themselves? And if brains are computers of some kind, what do computer designers have to say about recent discoveries in neurobiology (and, conversely, what might neurobiologists do to improve the working of computers)?
The imaginativeness of these ambitions partly explains why the rest of the world took two or three years to come to grips with what Japan was after. For the managers at Strasbourg now to say that they are threatened with being overwhelmed with grant applications from the more traditional reaches of molecular biology is not a bit surprising. Such has been the pace of discovery in the past decade that a host of interesting problems cries out for almost immediate solution. But that is no reason why the Strasbourg project should not continue to break new ground, unhampered by the now common pusillanimous criterion that only projects whose authors can virtually guarantee success will be allotted funds.

The hope must now be that this hatchet will be decently buried long before the crucial council meetings in November at which, among other things, a new secretary general must be nominated. There is too much at stake for failure to be contemplated. It is not sufficiently appreciated that the Human Frontier project is the only substantial source of funds for basic research whose recipients are not chosen in direct proportion to their national government's contributions to the fund. (In the past two rounds of grant-making, US researchers have done best out of Human Frontiers.) Research needs many more such organizations if it is ever to satisfy the purpose of being an international enterprise. If the project were to fail, perhaps because Japan pulled out, the failure would cast a long shadow.

Much of what needs doing in the next few weeks is fencemending at Strasbourg. But Japan must also be more active. During the past few months, for example, the Japanese have let it be known that, for fear of being overpossessive, they would play only a passive role in the choice of the next secretary general. That is not enough. What benefit would it be to the distinctive and probably unique research fund they have created if they were to sit on their hands and then find themselves lumbered with another secretary general with whom they could not get along?

\section{Foothold in Bosnia}

The world's diffidence at intervention in Bosnia is understandable, but should not be taken to extremes.

DR Boutros Boutros Ghali, the new and energetic secretary general of the United Nations, is right to tell the international community that there are more atrocities in Somalia 